\title{
Placing the et al. Back in Mendez v. Westminster: Hector Tarango and the Mexican American Movement to End Segregation in the Social and Political Borderlands of Orange County, California
}

\section{David-James Gonzales}

This article focuses on unheralded actors and events. I have chosen to center its narrative on the emergence of a civil rights movement among the Mexican colonias and barrios of Orange County, California. This is an important area of investigation within civil rights scholarship, as the desegregation battles that culminated in the 1954 ruling of Brown v. Board of Education had precedence in the southern California municipalities of Westminster, Santa Ana, Orange, El Modena, and Garden Grove. Employing the experiences and activism of Hector Tarango and the unheralded grassroots efforts leading up to the Mendez et al. decision as a case study for examining the emergence of a Mexican American civil rights movement in postwar Orange County, this project examines the intersections of race, space, and politics among Mexican Americans in southern California. With a particular focus on multiracial communities, such as Boyle Heights, and segregated spaces, such as Orange County, this project adds a spatial dimension to the identity formation and political mobilization of postwar Mexican Americans. Viewing public spaces-such as streets, convenience stores, classrooms, the workplace, and the courtroom-as contact zones in which members of various ethnoracial and cultural groups express competing identities, politics, and visions of society, this article merges the scholarship of borderlands history, critical geography, and interracial civil rights history to point out the ways in which public space in Orange County existed as a type 
of social and political borderlands in the politicization of second-generation Mexican Americans.

On a Sunday afternoon in 1932, an adolescent, Hector Tarango, was attending Sunday worship services at a Methodist congregation in El Modena, California. On his way inside the chapel, Hector noticed the peculiar sight of two elementary schools standing adjacent to each other, albeit separated by an open field and a wire fence. Hector observed that one of the schools, Roosevelt Elementary, was noticeably newer-featuring Spanish Mission-style architecture with a clean stucco exterior, columns, large commons areas, and a row of palm trees. The other school, Lincoln Elementary, had clearly fallen into disrepair, having a much older brick exterior and a less inviting landscape. On learning that the pristine-looking Roosevelt was for white students only while Lincoln was reserved for Mexican students, Hector recalled, "That shook me up tremendously, because I didn't realize they were doing that [segregating Mexican American schoolchildren]."1

Born into an ethnic Mexican working-class family and raised in multiracial communities, such as Clifton, Arizona, and the East Los Angeles neighborhood of Boyle Heights, Hector developed interethnic relationships with peers and neighbors that produced a multicultural understanding of the world around him. Hector's multiracial worldview was abruptly challenged that Sunday afternoon with the realization that one's language, culture, and skin tone provided justification for second-class treatment. Running counter to his lived experience, Hector was politicized at an early age by the segregated landscape of Orange County. Lacking a college education or any other type of formal training, Hector drew from his multicultural experiences and his hybridized Mexican American identity as the impetus for a lifetime of community service and social activism aimed at curtailing civil injustice. Years after his initial experience with racial discrimination, Hector became a key figure in the grassroots efforts that led to the landmark decision Mendez et al. v. Westminster School District et al. (1947), which ended de jure segregation in California's public schools and "served as a dry run" for the decision in Brown v. Board of Education (1954) seven years later. ${ }^{2}$

On February 18, 1946, the senior district court judge of Los Angeles, Paul J. McCormick, ruled in favor of plaintiffs Gonzalo Mendez, William Guzman, Frank Palomino, Thomas Estrada, and Lorenzo Ramirez in the class-action lawsuit Mendez et al. v. Westminster et al. Sending shockwaves throughout the Juan Crow Southwest as well as the Jim Crow South, the Mendez et al. decision was a watershed moment for the educational rights of nonwhites in the United States and set the stage for a number of civil rights victories in court decisions and legislative actions over the next twenty years. Thanks to a number of community activists, journalists, scholars, and educators over the past sixty years, many have come to know the history and significance of the Mendez et al. decision. ${ }^{3}$ Lesser known, however, is the central role of community organizing in bringing the case to trial and the small group of local citizens, community activ- 
ists, and parents who stood up to the de facto practices of racial segregation that had existed within the California school system since $1858 .{ }^{4}$ Within this small group of activists, the efforts of a local insurance salesman and photographer, Hector Tarango, were crucial to organizing local opposition into a concentrated movement to end de jure segregation throughout California schools and to fight a broader struggle against the discrimination of Mexican American workers and communities.

\section{The Role of Place in the Activism of Hector Tarango}

Hector Ruben Tarango was born in the small isolated mining town of Clifton, Arizona, in 1919. His parents, Ponciano Tarango and Maria Parades, emigrated from Mexico in 1911 and 1910, respectively, and settled in the Shannon Hill Spanish section of the Clifton precinct. Ponciano, whom Hector would later describe as "traditionally Mexican," worked as a laborer in the adjacent Clifton-Morenci copper mines - an industrial magnet for thousands of migrant laborers who came to the region from Europe, Latin America, and Asia. Maria, a "nontraditional Mexican" according to Hector, was a college graduate, former Baptist missionary, and schoolteacher who chose to stay home and care for Hector and his younger sister, Ethel. ${ }^{5}$ By the age of six, Hector developed a serious hip infection that was later identified as a rare form of tuberculosis. Receiving a medical sponsorship from their local Baptist congregation, the Tarangos moved to Los Angeles to seek medical treatment for their young son. While Hector went through a long and arduous recovery, his family settled in the ethnically diverse East Los Angeles community of Boyle Heights. Although the effects of the disease left him disabled for the remainder of his life, Hector was determined that it would not hold him back from staying active and being involved in those things he felt most passionate about. ${ }^{6}$

Arriving in Boyle Heights during the early 1920s, the Tarangos encountered a cultural landscape quite different from the one they had left in Clifton. Indeed, after experiencing the deep-seated racial discrimination and segregation of the Clifton-Morenci region, the East Side of Los Angeles seemed like a multicultural paradise due to the prevalence of multiracial spaces in which ethnic Mexicans, Japanese immigrants, African Americans, Jews, and other ethnic Europeans coexisted in neighborhood streets, schools, churches, parks, and businesses. ${ }^{7}$ Renting a small house on the eleven-hundredth block of South Dacotah Street, the Tarangos' immediate neighbors composed a small cross section of Boyle Heights' broader demographics. Moving southwest along South Dacotah Street, most of the homes were occupied by ethnic Mexicans, with the exception of three households inhabited by Syrian, Russian, and Anglo-American families. To the rear of the Tarango property was a block of homes facing Euclid Street. Moving southwest along Euclid resided three Russian families, three Armenian families, two Anglo-American families, and one Italian, Austrian, and Mexican. One block to the west of the Tarango property was South 
Fresno Street. Heading south on Fresno dwelt three Chinese families, one Irish family and another from New Zealand, and two ethnic Mexican families. ${ }^{8}$

As the city's "most ethnically diverse neighborhood" from 1920 to 1950, Boyle Heights offered the Tarangos ample opportunity to interact with people from various races and cultures in public spaces, such as Hollenbeck Park or the movie theaters, grocery stores, barbershops, delis, and other businesses thriving along Brooklyn Avenue. ${ }^{9}$ Additionally, fraternal organizations, religious institutions, and the YWCA-established International Institute of Los Angeles sponsored cultural events that celebrated notions of cultural pluralism amidst the nativism of the interwar era. By encouraging "the American-born children of immigrants to retain the language and distinct cultural traditions of their parents," the residents of Boyle Heights promoted a multicultural vision of society that contrasted with the repatriation drives and residential restrictive covenants of their day. ${ }^{10}$ Further, popular music, such as jazz and swing, played a contributory role in promoting cross-cultural interaction throughout the community as it echoed across dance halls, ballrooms, music stores, homes, and schools. Bringing youth and adults of various races together in public and private spaces, a "multicultural urban civility" developed around communities such as Boyle Heights, breaking down the barriers of racial stereotypes and challenging the segregated landscape of the greater Los Angeles region. ${ }^{11}$ Despite its multicultural composition, however, life along the East Side of Los Angeles was far from ideal. Indeed, studies of the mainly working-class immigrant populations residing in the area have addressed the prevalence of dilapidated housing, poor health, hard labor conditions, and cultural struggles against assimilation that permeated the lives of many ethnic Mexicans, Asians, blacks, and ethnic Europeans. $^{12}$

In the case of Hector Tarango, however, growing up in a multiracial community such as Boyle Heights shielded him from more blatant experiences with racial discrimination, such as the entrenched forms of housing and workplace segregation that existed in other parts of southern California and the broader Southwest. ${ }^{13}$ Arriving in Boyle Heights just in time to begin his primary education, Hector attended integrated schools where he was able to build friendships with children of Anglo-American, ethnic European, Jewish, Japanese, Chinese, and African American descent. Unhindered by feelings of inferiority resulting from the humiliation and degradation of school segregation, Hector's early experiences at school and within the community cultivated his views of societal membership, social justice, and politics long before he became politically active. $^{14}$

While seemingly mundane, these early experiences in the life of Hector Tarango intersect with many members of the Mexican American generation and later proved pivotal in shaping not only his future activism but also the contributions of an entire generation to the development of a civil rights movement among ethnic Mexican populations. Beginning with the communities of his childhood, Hector was exposed to multiracial spaces and multicultural environ- 
ments that shaped his view of the world. Since the initial mass migrations of Mexican laborers during the early twentieth century, the American-born children of Mexican descent had been raised in mining towns, agricultural fields, and ethnic enclaves that presented a complete demographic and socioeconomic contrast to the majority of Anglo-American society. As in Hector's case, the multiracial composition of these communities led to the development of interethnic relationships. ${ }^{15}$ And while many of these urban enclaves and agricultural colonias were not a utopian model of interracial harmony and coexistence, such close proximity often resulted in friendship, romance, and interethnic cooperation. Thus, in many instances, the seemingly ordinary experiences of Mexican Americans within interracial spaces throughout the Southwest promoted the blending of racial, cultural, and national identities that shaped both the complexity of Mexican American identity and their response to racial discrimination.

\section{Place and the Segregation of Mexican School Children in the Orange County Borderlands}

Provided the opportunity by family friend and later League of United Latin American Citizens (LULAC) organizer William "Henry" Wheat, the Tarango family accepted an offer to take over the management of a small grocery store along North Cypress Street in Orange, California. Moving into the Cypress Street Mexican barrio in 1932, the Tarangos experienced an entirely different sociocultural landscape than the one they left behind in Boyle Heights. As a product of the region's dependence on industrial citrus agriculture, the North Cypress barrio developed in the shadow of the packinghouse owned by the Santiago Orange Growers Association. Located about a block south of the Tarango's grocery and residence, the Santiago packinghouse was situated next to the Southern Pacific railroad tracks. Forming the barrio's western boundary, the tracks of the Southern Pacific were the economic artery of the regional economy as they provided the means for the distribution of the county's most lucrative crop: Sunkist-brand Valencia oranges. Located at the corner of North Cypress and West Palm Avenue, the Santiago packinghouse solidified the barrio's southwestern edge. Heading east of the packinghouse along West Palm, the barrio extended three blocks until it reached Glassell Street and then moved north two blocks to its northeastern limit at Walnut Avenue. Heading west along Walnut back toward the Tarango grocery, the North Cypress barrio formed a two-by-three-block rectangle. Occupied almost entirely by ethnic Mexicans, the barrio was effectively cordoned off socially, culturally, and physically from the Anglo-American populations residing east of Glassell near the city's central plaza. ${ }^{16}$

At thirteen years old, Hector became abruptly aware of the ethnoracial dynamics of Orange County shortly after his family's move to the region. By the 1930s, each of the county's major cities - including Santa Ana, Anaheim, Ful- 
lerton, and Orange - maintained segregated public schools, parks, swimming pools, and movie theaters. ${ }^{17}$ Due to his age and physical handicap, however, Hector did not attend the segregated Cypress Street Mexican school although it was located within a few blocks of his family's store. Yet, despite his initial good fortune, Hector encountered the humiliation of segregation in a more benign setting while attending church in the adjacent town of El Modena. Recalling his initial experience with racial discrimination, Hector stated, "I was only in [my] teens then," but "from then on, I started realizing that they were discriminating against ... our children." Devastated by the scene of the lowly Lincoln Elementary (a Mexican school) contrasted by the elegance of Roosevelt Elementary (an Anglo school), Hector struggled to make sense of a reality that contrasted so sharply with his lived experience. He remembered, "In Los Angeles, we didn't have any segregation." 18 However, while Hector may not have been aware of school segregation as a child, by the early 1930s it had become common practice throughout California's lucrative "Citrus Belt."19

Indeed, contemporary accounts and court transcripts described the stark differences between Anglo-American and Mexican American schools throughout Orange County during the 1930s and 1940s. In El Modena, the AngloAmerican school (Roosevelt Elementary) was described as styled after the old California missions, with a clean stucco exterior, columns, and a row of palm trees. The Mexican school (Lincoln Elementary) was a darker and much older brick building, separated from Roosevelt by a baseball diamond some 120 yards away. ${ }^{20}$ Southwest of El Modena was the city of Westminster, which had its own segregated schools: Westminster Grammar (Anglo) and Hoover Elementary (Mexican). Parents noted that Hoover was located next to a cow pasture and did not have a cafeteria. Since the teachers of the Mexican American children did not allow them to eat inside the classrooms, they were forced to do so outside, on the ground, with flies swarming overhead. ${ }^{21}$ Describing the disparities between Anglo and Mexican schools in Westminster, journalist and social activist Carey McWilliams stated, "There were two schools in Westminster: a handsomely equipped school with green lawns and shrubs for the Anglo-Americans; and a Mexican school whose meager equipment matches the inelegance of its surroundings." ${ }^{.22}$

Aside from the striking differences between the conditions of building facilities, the curriculum, pedagogy, and treatment of students differed greatly between the Mexican and Anglo schools. For the most part, the curriculum and instruction of Mexican American children served to support the socioeconomic system that existed in the surrounding agricultural communities. ${ }^{23}$ This meant that while Anglo children were taught academic subjects that would prepare them for further educational advancement, Mexican children were taught vocational trades - such as gardening, boot making, blacksmithing, carpentry, basketry, and sewing - suited for the more labor-intensive occupations along the bottom rungs of the socioeconomic strata. ${ }^{24}$ School districts also worked with local agribusinesses to adjust the schedules of Mexican children so as to 
coincide with their need for low-wage seasonal labor. In the Southwest and particularly in southern California, "Mexican schools" typically began at 7:00 a.m. and adjourned by noon so that children could join their parents in the agricultural fields and assist in the harvesting of the region's lucrative citrus groves and walnut orchards..$^{25}$

Further, segregation existed along the lines of gender as well as race. According to historian Gilbert Gonzalez, "The pattern of segregation tended to reinforce the traditional sexual division of labor within the Mexican family and to add and develop those divisions peculiar to an advanced capitalist society." ${ }^{26}$ The education of Mexican girls presented a particular area of focus and concern for educators, administrators, and social scientists, as there was a dualistic function in the education of these children. Like the boys, Mexican girls were trained vocationally in order to prepare them for a future in menial service sector occupations, such as laundry workers, domestic servants, and seamstresses; however, they were also taught homemaking in order to teach them how to be good Anglicized housewives and mothers. ${ }^{27}$ The educational curriculum and instruction of Mexican children thus attempted to assimilate and "Americanize" them into certain aspects of Anglo-American society. Ironically, while Mexican Americans were not deemed worthy of equal educational and recreational facilities, in those spaces where segregation was not reasonable - such as the use of a racialized workforce within the local economy that at times forced interracial interaction-Anglo-Americans wanted to ensure that the most offensive aspects of nonwhite culture had been "whitewashed" so as to not contradict the imagined existence of a homogeneous American population and culture.

\section{Motivations for Mexican American Activism in the Orange County Borderlands}

Even though Hector did not attend segregated schools himself, his reaction to the segregation of Mexican American schoolchildren fueled his political activism. Further, as we shall see, Hector's response to the spectacle of racial discrimination was a result of a hybridized Mexican American identity forged in the racially stratified social and political borderlands of Orange County ${ }^{28}$ In other words, it was not his Mexican heritage or his American birthright alone that could adequately explain his repulsion to the scene of Lincoln and Roosevelt elementary schools but rather the union of these identities within a particular place and time that motivated him to respond with resistance, social activism, and civic engagement. Representative of the second-class position that ethnic Mexicans retained during the first half of the twentieth century, the sight of Lincoln Elementary separated from Roosevelt by a mere hundred yards or so crystallized the terrain of Orange County's social, cultural, and political landscape. For Hector Tarango and Mexican Americans in Orange County, the struggle to overthrow school segregation played a central role in solidifying their identity and spurring their political mobilization. 
Living in and managing the small grocery in the city of Orange put the Tarangos in a position to become familiar with various members of their community. In addition to the network of contacts Hector was exposed to through the family business, he became active on his own accord and developed relationships with middle-class business owners - such as Santa Ana store owner Cruz Barrios and Santa Ana funeral parlor owner Manuel Veiga. In a conversation with Cruz Barrios during the early 1940s, Hector mentioned the disturbing scene of racial segregation he had witnessed in El Modena ten years earlier. Responding to Tarango's recollection of the experience, Cruz was not at all surprised and subsequently responded with, "Yeah, I know all about it. We were very disturbed . . . because our fighting group is coming home ... and their kids are being segregated, and that isn't right." ${ }^{\prime 29}$ After deciding they had to take action against the injustice of school segregation, Hector and Cruz enlisted the support of Isadore Gonzales, a salesclerk at the local JC Penney store, and Manuel Veiga in forming the Latin American Voter's League (LAVL) in Orange County. ${ }^{30}$ During the early to mid-1940s, this group formed the first of three community-focused organizations that Hector would play a central role in establishing throughout Orange County. ${ }^{31}$ These grassroots organizations, at least in Hector's eyes, were instituted with the specific intent of building local support to desegregate the school system and fight for the rights of Mexican Americans.

Once their initial conversations led to a shared desire for direct action and organization, the first order of business for the LAVL was to raise community awareness against this gross violation of Mexican American rights. This was an important first step in the Orange County desegregation movement, as many families - both Anglo and Mexican - were either seemingly content with the existing system or too afraid of the consequences should they speak out. In a 1991 interview, former El Modena resident, World War II veteran, and Lincoln Elementary student Bob Torres explained the sense of indifference that existed within the homes of certain members of the Mexican community. Referring to the segregation that existed within the city of El Modena and particularly the school system, Mr. Torres stated, "I myself . . . wasn't aware of it, because I felt comfortable with it. Nobody was hurting me. I never felt that they were depriving me of anything, until later I learned that they did. Once we found out that we had been wronged, then we wanted to do something about it." ${ }^{32}$ Another resident of El Modena at the time, Dan Gomez, echoed a similar sentiment in his interview: "There was just very little involvement. There was really no concern about it ... it was like well, if no one says anything about it, it's not really happening. And that's really the way it was handled. Nobody says anything, it doesn't exist." ${ }^{\prime 3}$ While some families were too apprehensive to challenge the system directly, they did not necessarily remain silent, choosing instead to hold their own forms of individual protest by not permitting their children to attend school or other segregated facilities, such as community pools and movie theaters. ${ }^{34}$ Referring to the void of courageous leadership within the community 
prior to the seminal efforts of Tarango and his cohort of unheralded activists, Mr. Gomez stated, "I think that was one of the things that got us going, because you needed someone ... outspoken. Someone who wasn't afraid to start making a few waves and afraid that the establishment would come back and pound him." 35

The sentiments and actions related by Mr. Torres and Mr. Gomez provide insight into the various ways Mexican Americans formed their identities and politics in Orange County's social and political borderlands. The indifference felt by some community members was largely the result of ignorance, which was an intentional by-product of their segregated society. While most families were certainly aware of the existence of segregation throughout Orange County's agricultural communities, many others were not intimately acquainted with its grosser disparities, as they and their children spent the entirety of their day laboring in the fields and, therefore, did not attend school or associate much outside of the protections of their ethnic enclave. ${ }^{36}$ Further, while withholding children from school or other segregated facilities may have seemed ineffective or counterproductive to overturning a segregated society, such practices sowed the seeds of future activism and politicization. This kind of activity, in other words, was fundamentally political and important groundwork for what are often the more recognized and lauded forms of political activism. Moreover, perhaps these communities were waiting for a leader and not necessarily a prominent businessman, politician, academic, or civil rights figure. In conversations between folks such as Tarango and his associates, it became increasingly clear that an ethnic identity-based mobilization of organic community leadership was necessary if something was to be done about the second-class treatment of Orange County's Mexican Americans. ${ }^{37}$

This was certainly the circumstance with Hector, his compatriots, and other members of the Santa Ana, Westminster, El Modena, and Garden Grove communities. But fighting segregated schools within California's Citrus Belt was not a phenomenon developed solely out of World War II activism. Indeed, postwar Mexican American mobilizations had precedence in 1919, when members of the Santa Ana Mexican community protested the implementation of segregated schools by appealing to members of their local school board, and in 1931, when "the nation's first successful desegregation court case" was won by a group of Mexican parents in the ruling of Roberto Alvarez v. the Board of Trustees of the Lemon Grove School District. ${ }^{38}$ In both of these earlier instances, ethnic and political identities emerged to drive political action within segregated agricultural communities.

\section{The Formation of Orange County's Desegregation Movement}

In the case of Mendez et al. v. Westminster School District et al., several individuals began their own personal battles with segregation before uniting to file the class-action suit against the Orange County school system in 1945. 
Such was the case with Felicitas Fuentes, who testified during the Mendez et al. proceedings that "a lot of . . mothers," including herself, Virginia Guzman, and Mrs. Manuel Ochoa (both of whom were also witnesses during the trial), had either spoken with individual school administrators and district officials or appeared before the defendant school boards over the previous three to four years to request that their children be allowed to attend white/Anglo schools. ${ }^{39}$ As with earlier efforts in 1919, these initial protests were rebuffed. Yet, as detailed by Nadine Bermudez in her study of the fifteen women whose names and families are recorded in the court transcripts of Mendez et al., Mexican American mothers were often the first in their families and communities to confront school and district officials over the policy of segregation. During these early and recurring interactions with school administrators, the protests of Mexican American women anticipated the arguments made by David C. Marcus, attorney for the plaintiff families, years prior to the filing of the lawsuit in March 1945. ${ }^{40}$ These complaints were that (1) school zones and district boundaries were enforced arbitrarily, (2) the system of segregating Mexican children was discriminatory and racially motivated, and (3) Mexican school facilities, materials, and instruction were unequal to those provided to white/Anglo children.

Immediately following the formation of the LAVL between 1942 and 1943, Tarango and his associates began working with individual families, such as the Fuenteses, Guzmans, and Ochoas. Driving from one barrio/colonia to another, the LAVL searched for families willing to speak out against the policy of segregation and encouraged them to make their complaints in groups before regularly scheduled school board meetings. Such was the case on October 25, 1943, when Mrs. Leonides Sanchez and Mrs. Frank Garcia appeared before the Santa Ana Board of Education to "protest the denial of a request to send their children" to the nearby Franklin (white/Anglo) School. According to the board's minutes, the women "wished to have their children educated in an American School so that they would have all the advantages of American children and learn to speak English as Americans do." The mothers also alleged that "it is a matter of discrimination when Mexican children are forced to go to the Mexican School." ${ }^{\prime 1}$ Strikingly, the complaints of Sanchez and Garcia prefigured another key tactic successfully applied for the first time in Mendez et al. that was also used successfully in Brown v. Board of Education eight years later. This was the inference that segregation prevented social interaction between ethnic Mexican and Anglo/white children, which, as argued by University of California anthropologist and sociologist Dr. Ralph Beals, would aid in assimilating or Americanizing Mexican children. ${ }^{42}$

Additionally, the initial efforts of Hector Tarango and the LAVL paralleled those of the Gonzalo and Felícitas Méndez family. At about the same time (around 1943) that Hector, Cruz, Isadore, and Manuel formed the LAVL and began attending school board meetings, the Méndez family had recently moved to Westminster to lease the forty-acre asparagus farm belonging to Seiko Munemitsu. As a result of President Franklin D. Roosevelt's Executive Order 
9066, the Munemitsus had recently been interned. The move put the Méndez family within close proximity to the Westminster Main (Anglo) Elementary School, and on the initial attempt to enroll their children Sylvia, Gonzalo Jr., and Jerome, they were denied admission. ${ }^{43}$ The rejection shocked the Méndez family - in particular Gonzalo, who had attended a racially integrated Westminster Main in the 1920s - and immediately preceded the activism of Gonzalo and Felícitas as they protested the decision to the school principal and school board independently before joining with the efforts of Hector's LAVL to obtain the legal counsel of David C. Marcus. ${ }^{44}$

On the evening of September 19, 1944, Cruz Barrios, Manuel Veiga, and Hector Tarango attended the monthly meeting of the Westminster School Board as representatives of the "the Latin American Voters Counsel [sic]." The minutes from this meeting provide the earliest documentation of the grassroots activity spearheaded by Tarango and his associates, which had been in the works for some time up to that point. According to the record,

Representatives of the Hoover school Mexican colony were
present, and accompanied by Messrs. Barrios, Vega [sic], and
Diago [sic] [note that this is a misspelling of Tarango], of
the Latin American Voters Counsel. The Group presented a
petition to the school board in which it called attention to the
fact of the segregation of the American children, of Mexican
descent, and children of non-Mexican descent. A definite re-
quest that the Mexican school at Hoover be unified with the
Westminster school was made. ${ }^{45}$

The petition presented to the school board contained the signatures of twenty-six parents, all of whom had children attending Hoover Elementary (Mexican school). The petition stated that half of the parents were "American born" and that their "American-born" children were victims of "racial discrimination." In a united voice claiming the privileges of their American citizenship or the citizenship of their children, the parents of Westminster called for an immediate "doing away with ... segregation." ${ }^{46}$ Belligerently, the board responded by attempting to distance themselves from their illegal actions by stating "that the system of segregation had been inherited by them and that they had considered the problem before that date. ${ }^{947}$ The board's comments were a flat-out misrepresentation of actual facts, as the minutes prior to September 19,1945 , did not indicate that any such discussion ever took place. While the Westminster board had attempted to pass a school bond measure to raise funds for the construction of new facilities, these improvements were to be made to the Anglo school (Westminster Main) and did not appear to be of any benefit to the Mexican children attending Hoover. ${ }^{48}$

About a month later, on October 23, 1944, at the encouragement of Tarango's LAVL, another coalition of Mexican American parents attended a meeting 
of the Santa Ana Board of Education to protest the segregation of their children. For some, such as the Sanchez and Garcia families, this was their second or third time appearing before the board. ${ }^{49}$ At this particular meeting, one of the parents, William Guzman, was accompanied by his attorney, Charles Martin. This local coalition of parents and community activists charged the board with racial discrimination based on Franklin Elementary's (Anglo school) policy of refusing admission to children of Mexican descent. Seeing that such accusations had little effect on the board, Mr. and Mrs. Guzman also pointed out that they lived much closer to Franklin and that their son Billy had to encounter heavy and dangerous traffic conditions as he walked to the Fremont (Mexican) school. Defiantly, the school board refuted these claims and stated that since Billy had experienced no problems arriving at school safely in prior years, any danger posed to him should be mitigated as he grew older. Sensing that they had not fully pacified the Mexican parents, the board requested ninety days to determine how to best respond to their request. ${ }^{50}$

Back in Westminster, with the help of Hector Tarango and the LAVL, what would become the leading plaintiff families of Mendez et al. acquired the services of attorney David C. Marcus from Los Angeles. ${ }^{51}$ On January 10, 1945, both Mendez and Marcus petitioned the Westminster School Board to integrate the Mexican and Anglo schools. In his letter, Mr. Marcus alleged that, in his opinion, "there was discrimination being practiced in the district." from legal counsel rather than a group of Mexican parents, the accusation of discrimination, coupled with the implication of litigation, jolted the school board into seriously considering the Mexican American community's protests as more than harmless disturbances to their weekly meetings. As the minutes of the latter January 10, 1945, meeting indicate, the Westminster School Board was in the process of seeking legal advice in order to determine an official position on the segregation of Mexican children. ${ }^{53} \mathrm{~A}$ week later, on January 16, 1945, Gonzalo Mendez reappeared in front of the school board alongside a Mr. Youngyoung as representatives of the "Mexican speaking peoples." ${ }^{44}$ Facing inquiries about their inaction over the requests of the Mexican American parents to integrate the Main and Hoover schools, the board continued to insist that they had inherited the problem from the previous school board and that funding, housing, and construction limitations prevented integration..$^{55}$ Tellingly, between the board meetings of January 16 and March 12, 1945, neither the Westminster nor the Santa Ana School Board discussed the issue of integration until their notification of the Mendez et al. filing in federal district court. ${ }^{56}$ Despite the repeated protests of the Mexican American community, the Westminster, Santa Ana, El Modena, and Garden Grove districts persisted in the segregation of Mexican American children, notwithstanding the fact that neither California law nor the school code gave them legal authority to do so.

Unsuccessful in their attempts to avoid litigation by appealing to the school districts directly, on March 2, 1945, the Mendez, Guzman, Palomino, Estrada, and Ramirez families filed a class-action suit in federal district court on be- 
half of the 5,000-plus children in school districts throughout Orange County. Although unsuccessful in getting the school boards to respond to their initial protests, a small number of seemingly inconsequential Mexican communities throughout Orange County took a significant step forward in the battle to desegregate public schools throughout California and the nation. As noted earlier, this was not a battle that began in Orange County or even southern California, but the Mendez et al. case rose to such national prominence that the desegregation movement sparked by the early yet forgotten victories of Del Rio Independent School District v. Salvatierra (1930) and Alvarez v. Lemon Grove (1931) had been reawakened with heightened vigor and determination. ${ }^{57}$

Behind this renaissance of community activism and subsequently the increasing politicization of Orange County Mexican Americans, the pivotal leadership of Hector Tarango and the unheralded efforts of numerous children, families, and grassroots organizations contested the established racial hierarchy of Orange County's social and political borderlands. Through their actions of resistance, organization, and civic participation in public and private spaces throughout the region - streets, parks, local businesses, homes, and school and district offices-Orange County's Mexican communities emerged from out of the shadow of the larger Anglo-American polity. Beginning with the daily individual struggles and personal humiliation that resulted from their persistent marginalization, this Mexican American-led grassroots movement arose from the intimate and mundane conversations of family, friends, and neighbors to form a broad-based regional coalition that challenged the second-class citizenship of nonwhite children in California schools. While their experiences, organization, and response echoed the efforts of earlier struggles, the movement to desegregate Orange County schools lit a fire of resistance, community activism, and increasing civic participation that fueled the Mexican American civil rights movement of the ensuing four decades.

\section{From Orange County to the Nation and Back: Solidifying Victory in Mendez et al.}

The opinion of Judge Paul McCormick, handed down on February 18, 1946, leveled a tremendous blow against the segregated society that existed throughout California's Citrus Belt. Not stopping at the issue of segregation within California alone, McCormick directly attacked the practice of segregation within educational facilities writ large by opining, "A paramount requisite in the American system of public education is social equality. It must be open to all children by unified school association regardless of lineage [emphasis added]. ${ }^{.58}$ In an opinion later echoed by Brown v. Board of Education eight years later, McCormick determined that the segregation of Mexican American children was in violation of the Fourteenth Amendment's equal protection clause-implying that the doctrine of "separate but equal" was inherently un- 
equal — and thereby ordered the full and immediate integration of the Orange County school districts. ${ }^{59}$

Despite McCormick's injunction, however, the response from the districts involved a mix of reluctant cooperation and outright defiance. While the Westminster district opened its 1946-1947 school year by integrating the Main and Hoover schools, the districts in Santa Ana and El Modena were much more resistant. ${ }^{60}$ In spite of McCormick's bold declaration denouncing the overall existence of a segregated society, a portion of Orange County's “commercialcivic-citrus elite" 61 was unwilling to yield control over the region's socioeconomic and political hierarchy. Subsequently, a counterattack was mounted by members of the boards of education, the county board of supervisors, Associated Farmers, the chamber of commerce, the district attorney's office, and other local politicians, business owners, and residents to obstruct the integration of the Orange County school districts. ${ }^{62}$ As the backlash intensified, the efforts of Hector Tarango and his unheralded coalition of community activists became even more vital as they worked to uphold the law and defend their rights as American citizens.

Since McCormick's decision brought the national spotlight to the Mexican communities of Orange County, ${ }^{63}$ a number of civil rights leaders descended on the region to assist with the Mendez et al. appeal. Comprehending the potential national implications of a favorable decision in Mendez et al. - and indeed seeing it as a test case for the National Association for the Advancement of Colored People (NAACP) in its attempt to overturn Plessy v. Ferguson (1896) - the NAACP, the American Civil Liberties Union, the Japanese American Citizens League, and the American Jewish Congress filed a number of amicus curiae briefs in support of Judge McCormick's opinion. ${ }^{64}$ Further, representatives of LULAC, at the time the nation's most prominent Mexican American civil rights organization, also came to Orange County and after speaking with Tarango and his associates persuaded the founding members of the LAVL to join their national organization. Subsequently, on May 8, 1946, Manuel Veiga, Phillip Mendez, Hector Tarango, and Cruz Barrios were elected the founding officers of Santa Ana LULAC Council \#147. ${ }^{65}$ Although a late addition to the grassroots movement had begun three years prior, the backing of LULAC during the appeal provided modest financial support alongside access to the organization's national network of interracial coalitions. ${ }^{66}$

A short while after the formation of the LULAC Council in Santa Ana, Fred Ross was sent to Orange County by the American Council on Race Relations to consult and strategize with the region's nascent Mexican American leadership. ${ }^{67}$ As a young and aspiring social activist, Ross had a proven track record of organizing Mexican American communities in the Riverside barrios of Bell Town and Casa Blanca. While there, Ross experienced a considerable amount of success organizing Unity Leagues with local activist Ignacio Lopez. ${ }^{68}$ Unfazed by the Santa Ana and El Modena districts' refusal to adhere to 
McCormick's ruling, Hector Tarango and Fred Ross implemented a more aggressive strategy to place increasing pressure on the school boards.

The first order of business for Ross and Tarango was to establish a formidable voting bloc among the Mexican American population that would serve to check the power of the commercial-civic-citrus elite. According to Hector's estimate, by the summer of 1946, Orange County had approximately 17,000 Mexican Americans who were eligible to vote-90 percent of whom were unregistered. ${ }^{69}$ Those who were registered, however, were scattered so thin throughout the county that, even if they did vote together, their voices would be drowned out by the more organized and unified white vote. With the help of parents and nascent activists in the communities of El Modena, Delhi, and Artesia, Tarango and Ross instituted a voter registration campaign. Amazingly, within two weeks' time, Tarango and Ross had found enough local leadership to set up Unity Leagues in Delhi, Artesia, and El Modena and registered more than 200 new voters. ${ }^{70}$ This initial success was only the beginning. Within the ensuing weeks, Tarango, Ross, and freshly recruited Unity League members registered 300 additional voters in El Modena alone and over the ensuing two years registered 15,000 new voters throughout the county. ${ }^{71}$

With local leadership in place, Mexican Americans began to plan their attack on the various problems afflicting their neighborhoods. In house meetings and more formal community gatherings, Orange County colonias established forums and committees that discussed barrio issues and used a system of popular consent to prioritize their focus on those concerns that affected the largest portion of residents. In Delhi, for example, Unity League members chose to fight a zoning ordinance and lobby for community improvements, such as the installation of streetlights. Meanwhile, the leagues in Artesia and El Modena joined forces to contest the persistent segregation of their children in the El Modena district and also supported a statewide fair employment practices bill (Proposition 11) in the upcoming November 1946 election. ${ }^{72}$ Armed with an increasingly unified and determined coalition of Mexican American voters, Orange County barrios used the very political process that had previously allowed for their marginalization to end de jure school segregation for good.

With the opening of the 1946-1947 school year, the Santa Ana and El Modena districts persisted in segregating Mexican American schoolchildren in open defiance of McCormick's decision earlier that year. Continuing to cite teacher shortages, space limitations, and financial issues as reasons for not adhering to McCormick's injunction, the boards of education attempted to stall integration until the appeals process was completed. ${ }^{73}$ Having discussed their response should the districts continue to resist desegregation, Tarango, Ross, and Unity League members continued to hold protests during board meetings and sought further legal recourse. ${ }^{74}$ On the evening of September 12, 1946, Ross and Tarango appeared before the Santa Ana Board of Education. The minutes of the school board meeting record Ross as being "antagonistic and belligerent concerning the matter of Mexican American children." Moreover, 
Ross threatened to have "the Board of Education ... cited for contempt" should they persist in denying the admission of Mexican children to Anglo schools. ${ }^{75}$ In an attempt to ease tensions, Tarango arranged for negotiations between four members of the school board and four members of the Mexican American community over dinner. The minutes of the following board meeting on September 14 show that the dinner was successful in gaining modest concessions from school board members. ${ }^{76}$ While the agreement with the school board admitted Mexican American students into Anglo schools only on a case-by-case basis as such spots became available, the fact that the Santa Ana School Board now found itself in the awkward position of being forced to negotiate with members of the ethnic Mexican community was a significant development that signaled the ascendance of Mexican American political power in the region. ${ }^{77}$

While the Santa Ana School Board was willing to compromise until a more amicable solution could be reached, the board in El Modena refused to be moved on the issue of integration. True to their word and with the assistance of Tarango and Ross, the El Modena Unity League filed contempt charges against the district and collected 500 signatures on an antisegregation petition. ${ }^{78}$ Emboldened by its rapidly expanding membership — surpassing 100 at the timeUnity League leadership in El Modena began to discuss how to best use their newly acquired voting power, which they now reasoned surpassed the influence of the local commercial-civic-citrus elite. In a Unity League special executive committee meeting held a few days before the October 9, 1946, school board meeting, Tarango, Ross, and league leadership strategized a plan to brandish the Mexican American vote in case the school board continued to resist their calls for integration. ${ }^{79}$

Interestingly, the official minutes of the October 9 meeting of the El Modena Board of Trustees differ greatly from the notes taken by Unity League members. While the school board notes mention the presence of Tarango, Ross, newly elected Unity League president Alex Lievanos, and a few other members of the Mexican American community, the recorder left out substantial portions of a highly contentious debate and an ultimatum given to the board by League members. After "launching an [hour long] attack" on board members over "the patent unfairness and illegality of a policy of exclusion based solely on proficiency in English," Unity League members were able to lure the school board into admitting that language was not the sole reason for preventing their children's admission into Anglo schools. Having confirmed what they knew to be true all along - that their children were segregated due to their ethnoracial heritage rather than language proficiency-Tarango slyly hinted that if the board did not act to rectify the issue of segregation quickly, then the Mexican American community would be forced to do so for them "at the polls." Within one week's time, the local newspaper reported that beginning October 17, the Roosevelt and Lincoln schools would be merged for "operational efficiency." 80 While this act served to integrate only the schools rather than the children in each class, Mexican Americans did not have to wait long before both the Ninth 
Circuit Court of Appeals and the California legislature put an end to all forms of de jure educational segregation in California. ${ }^{81}$ Further, within the coming years, Tarango and the Mexican American community kept their promise to the school board by influencing the outcome of board elections from 1947 until the district's incorporation into the Orange Unified School District in 1953 - securing victories for Jesus Martinez and Primo Rodriguez along the way. ${ }^{82}$

\section{Conclusion}

Immediately following the Ninth Circuit's decision to uphold McCormick's ruling, California governor-and later presiding U.S. Supreme Court chief justice in the Brown v. Board of Education decision of 1954-Earl Warren asked the state legislature to send him a bill repealing sections 8003 and 8004 of the state Education Code, which previously allowed for the de jure segregation of Native American and Asian American children. Warren signed the bill shortly thereafter on June 14, 1947. On the heels of these momentous victories, Texas LULAC officials sued the Bastrop Independent School District for its categorical segregation of Mexican children. Resulting in a federal district court of Texas victory in 1948, Delgado v. Bastrop Independent School District outlawed the segregation of Mexican children in Texas and resuscitated LULAC's 1930 victory in Del Rio Independent School District v. Salvatierra, leading to the U.S. Supreme Court's decision in Hernandez v. State of Texas (1954) two weeks prior to the Brown v. Board decision. ${ }^{83}$ Although Mendez et al. was not cited as legal precedent in either oral arguments or the decision itself, Robert L. Carter, attorney for the plaintiffs alongside Thurgood Marshall, credited David Marcus and the Mendez et al. decision for giving him the idea to secure expert testimony from leading social scientists, such as Kenneth B. Clark, to verify the psychologically damaging effects of segregation on African American children. ${ }^{84}$ Thus, there is little doubt that the line of argumentation and series of both court and legislative victories leading up to Brown v. Board, all of which had their roots in Mendez et al., would have culminated in the Brown decision without the efforts of unheralded Mexican American activists in Orange County. ${ }^{85}$

Established in the late nineteenth century as a collection of sparsely populated agricultural towns, Orange County is most commonly known for its once sprawling citrus orchards and theme parks and as a suburban extension of the multinucleated metropolis of Los Angeles. Lesser known, however, is the importance of Orange County in the national struggle to desegregate public education and, even lesser still, the centrality of the region in the development of the Mexican American civil rights movement. Despite their lack of presence in civil rights lore, the Orange County communities of Santa Ana, Westminster, Garden Grove, Orange, and El Modena were critical sites in the formation of a grassroots movement that played a central role in overturning de jure racial segregation throughout the nation. Emerging out of the seemingly mundane 
interactions between family, friends, and neighbors, Orange County's school desegregation movement was rooted in the cross-cultural interactions of ordinary people occurring in multiracial spaces throughout southern California. Interactions such as these shaped hybrid-like identities that in turn produced pluralist visions of society and its possibilities. Comprised of unheralded actors such as Hector Tarango and the parents, neighbors, and children who formed an organic coalition of indigenous community leadership, the victories of Mexican Americans in Orange County's social and political borderlands carried national implications for the success of the broader civil rights movement.

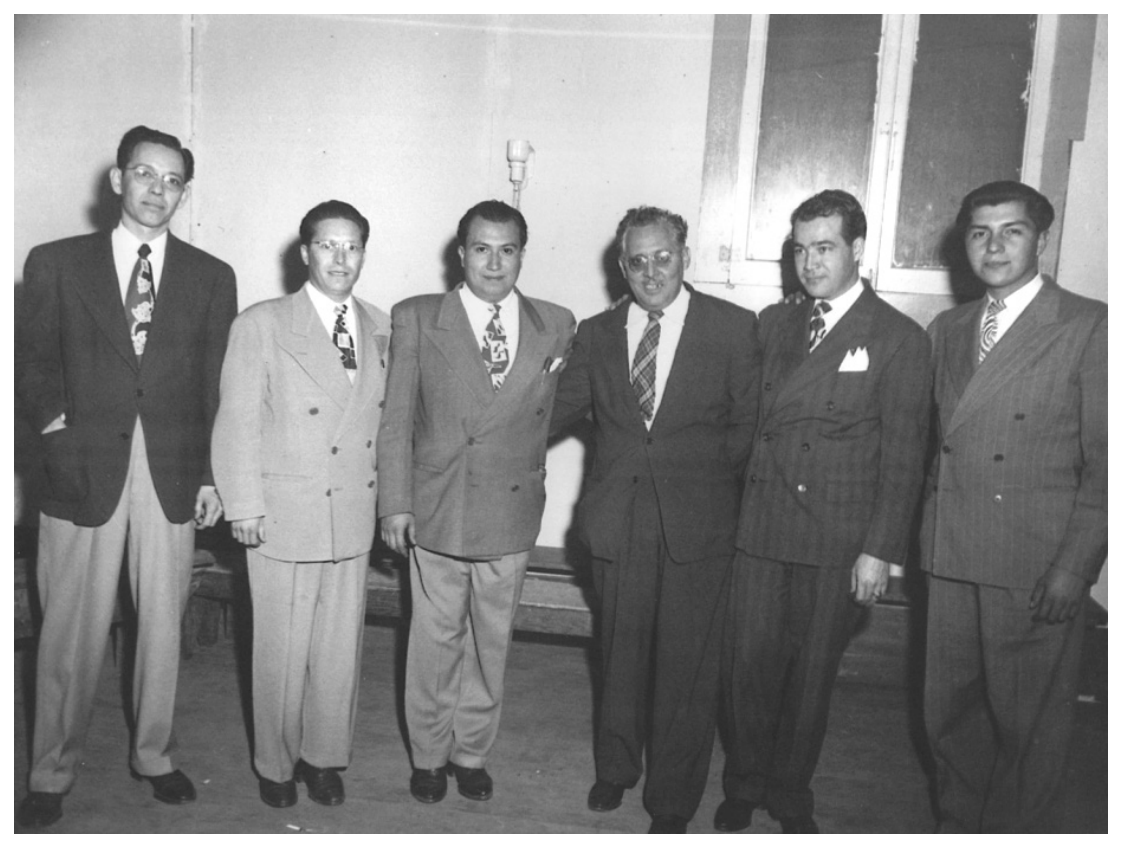

Figure 1: Founding members of the LAVL and later organizers of Santa Ana LULAC chapter 147 (around 1946). Hector Tarango is pictured left of center with Cruz Barrios right of center. ${ }^{86}$

\section{Notes}

1. Herman Gallegos, Eric Kutner, and Gilbert Padilla, interview with Hector Tarango, November 2005, Community Service Organization, History Project records, M1669, Department of Special Collections and University Archives, Stanford University Archives, Stanford, California (hereafter referred to as "CSO Tarango interview").

2. This comment was made by Robert L. Carter, who, as an attorney with the National Association for the Advancement of Colored People alongside Thurgood Marshall, presented oral arguments in Brown v. Board of Education. Vernon M. Billy, "The Echo of Mendez v. Westminster 70 Years Later," California School Boards Association, July 28, 2018, https://medium.com/@CSBA/ the-echo-of-mendez-v-westminster-70-years-later-b24d11438fe4\#.er2icu3cc. See also "Commentary, Effect the Mendez vs. Westminster Case from 1944 Had on the Brown vs. Board of Education Case 10 Years Later," Tavis Smiley, May 20, 2004. 
3. For more on the background and significance of Mendez et al. v. Westminster School Board et al., see Christopher Arriola, "Knocking on the Schoolhouse Door: Mendez v. Westminster, Equal Protection, Public Education, and Mexican Americans in the 1940's," La Raza Law Journal 8, no. 166 (1995): 166-207; Gilbert G. Gonzalez, "Segregation of Mexican Children in a Southern California City: The Legacy of Expansionism and the American Southwest," Western Historical Quarterly 16, no. 1 (January 1985): 55-76; Steven Wilson, "Brown over 'Other White': Mexican Americans' Legal Arguments and Litigation Strategy in School Desegregation Lawsuits," Law and History Review 21, no. 1 (Spring 2003): 145-94; Charles Wollenberg, "Mendez v. Westminster: Race, Nationality and Segregation in California Schools," California Historical Quarterly 53, no. 4 (Winter 1974): 317-32; Phillipa Strum, Mendez v. Westminster: School Desegregation and Mexican-American Rights (Lawrence: University Press of Kansas, 2010); and Nadine Bermudez, "Mendez et al. v. Westminster et al.: Mexican American Female Activism in the Age of De Jure Segregation" (PhD diss., University of California, Los Angeles, 2015).

4. Wollenberg, "Mendez v. Westminster," 317-18; Shirley Ann Wilson Moore, “"We Feel the Want of Protection': The Politics of Law and Race in California, 1848-1878," California History 81 , no. 3/4 (2003): 115 .

5. CSO Tarango interview, 1; Gonzalez, interview with Hector Tarango, April 15, 1989, Gilbert G. Gonzalez Interviews MS.R.144, University of California, Irvine, Special Collections. For detailed discussions of the socioeconomic conditions of the Clifton-Morenci mining district, see Ted Cogut and Bill Conger, History of Arizona's Clifton-Morenci Mining District: A Personal Approach, vol. 1 (Thatcher, AZ: Minning History, 1999); James Patton, History of Clifton (Clifton, AZ: Greenlee County Chamber of Commerce, 1977); and Phil Mellinger, "'The Men Have Become Organizers': Labor Conflict and Unionization in the Mexican Mining Communities of Arizona, 1900-1915," Western Historical Quarterly 23 (Fall 1992): 323-47.

6. CSO Tarango interview, 1.

7. Sánchez, Becoming Mexican American, 76-77. For examples of the intense anti-Mexican sentiment existent throughout the Clifton-Morenci region during the early twentieth century, see Rodolfo Acuña, Corridors of Migration: The Odyssey of Mexican Laborers, 1600-1933 (Tucson: University of Arizona Press, 2008), 119-41, and Linda Gordon, The Great Arizona Orphan Abduction (Cambridge, MA: Harvard University Press, 1999).

8. Bureau of the Census, Fourteenth Census of the United States, 1930, https://familysearch. org/pal:/MM9.1.1/MCRJ-YRR (accessed December 12, 2012).

9. Japanese American National Museum, Boyle Heights, 33.

10. Ibid., 38; Sánchez, Becoming Mexican American, 216-21; Anthony Macias, Mexican American Mojo: Popular Music, Dance, and Urban Culture in Los Angeles, 1935-1968 (Durham, NC: Duke University Press, 2008), 18.

11. Macias, Mexican American Mojo, 18-20.

12. Sánchez, Becoming Mexican American; Natalia Molina, Fit to Be Citizens: Public Health and Race in Los Angeles, 1879-1939 (Berkeley: University of California Press, 2006); Douglas Monroy, Rebirth: Mexican Los Angeles from the Great Migration to the Great Depression (Berkeley: University of California Press, 1999).

13. CSO Tarango interview, $1-3$. Due to a mixture of economic and demographic issues, the segregation of Mexican American children in California was limited mostly to the primary grades of traditional K-6 schools among agricultural populations. Gilbert G. Gonzalez, Labor and Community: Mexican Citrus Worker Villages in a Southern California County, 1900-1950 (Urbana: University of Illinois Press, 1994), 99-113; Charles Wollenberg, All Deliberate Speed: Segregation and Exclusion in California Schools, 1855-1975 (Berkeley: University of California Press, 1976), $116-17$.

14. CSO Tarango interview, $1-2$.

15. Ibid., 3; Allison Varzally, "Romantic Crossings: Making Love, Family, and Non-Whiteness in California, 1925-1950," Journal of American Ethnic History 23, no. 1 (Fall 2003): 3-54.

16. Phil Brigandi, A Brief History of Orange, California: The Plaza City (Charleston, SC: The History Press, 2011), 54-56; Orange Public Library, "Historic Orange Preservation Online," http://www.cityoforange.org/localhistory/default.htm (accessed December 12, 2012); Bureau of the Census, Sixteenth Census of the United States, 1940, https://familysearch.org/pal:/MM9.1.1/K94D86J (accessed December 5, 2012).

17. See Gonzalez, Labor and Community, and Lisbeth Haas, Conquests and Historical Identities in California, 1769-1936 (Berkeley: University of California Press, 1996).

18. CSO Tarango interview, 3.

19. Ibid. $173-75$

20. Strum, Mendez v. Westminster, 45-46; Arriola, "Knocking on the Schoolhouse Door,"

21. Arriola, "Knocking on the Schoolhouse Door," 173-75.

22. Carey McWilliams, North From Mexico: The Spanish Speaking People of the United States (New York: Praeger, 1990), 249-51. 


\section{David-James Gonzales}

23. For in-depth histories expounding the inequalities and connections between school segregation in California and local economies dominated by large-scale agricultural production, see Gonzalez, Chicano Education in the Era of Segregation; Robert Alvarez Jr., "The Lemon Grove Incident," Journal of San Diego History 32, no. 2 (Spring 1986); and Wollenberg, All Deliberate Speed.

24. Gonzalez, Chicano Education in the Era of Segregation, 137-38.

25. Ibid., 95, 146-47; Haas, Conquests and Historical Identities in California, 189-96.

26. Gonzalez, Chicano Education in the Era of Segregation, 138-39.

27. Ibid., 47-49; Natalia Molina, Fit to Be Citizens, 78, 115; Monica Perales, Smeltertown: Making and Remembering A Southwest Border Community (Chapel Hill: University of North Carolina Press, 2010), 185-208; Dorothy Roberts, "Who May Give Birth to Citizens? Reproduction, Eugenics, and Immigration," in Immigrants Out! The New Nativism and Anti-Immigrant Impulse in the U.S., ed. Juan F. Perea (New York: New York University Press, 1997), 205-19; Ruiz, From Out of the Shadows, 33-50, 72-98.

28. Gonzalez, interview with Hector Tarango, April 15, 1989.

29. CSO Tarango interview, 3.

30. Ibid.; Westminster Elementary School Board of Trustees, minutes, September 19, 1944 (Westminster School District Office, Westminster, California); Gonzalez, interview with Hector Tarango, April 15, 1989.

31. The names of these organizations are as follows: the Latin American Voters League (also referred to as the Latin American Organization), the El Modena Unity League, and Santa Ana LULAC Council \#147. See Margie Aguirre, "Letter to Tarango," and Strum, Mendez v. Westminster, 131; Santa Ana LULAC Council minutes, May 8, 1946, Community Service Organization, History Project records, M1669, Department of Special Collections and University Archives, Stanford, California; Fred Ross, unpublished autobiography, 14-15.

32. Christopher Arriola interview with Bob Torres, August 16, 1991, Mendez v. Westminster: research materials, M0938, Department of Special Collections, Stanford University Libraries, Stanford, California, Box 1, Folder 4.

33. Ibid.; Arriola interview with Daniel Gomez, July 26, 1991.

34. Ibid.

35. Ibid.

36. Arriola interview with Bob Torres, August 16, 1991; Matt Garcia, A World of Its Own, 50-78; Strum, Mendez v. Westminster, 40-41.

37. CSO Tarango interview, 3-4; Gonzalez, interview with Hector Tarango, April 15, 1989; Ross, unpublished autobiography, Fred Ross Papers, 39-40.

38. Gonzalez, Chicano Education in the Era of Segregation, 141; Alvarez, "The Lemon Grove Incident."

39. Bermudez, “Mendez et al. v. Westminster et al.," 181-89.

40. Mendez et al. v. Westminster School District of Orange County et al., 64 F.Supp. 544 (S.D. Cal. 1946).

41. Santa Ana Board of Education, minutes, October 25, 1943; CSO Tarango interview. See also Gonzalez, Chicano Education in the Era of Segregation, 190-92.

42. See "Reporter's Transcript of Proceedings," July 11, 1945, Mendez et al. v. Westminster School District of Orange County et al., 64 F.Supp. 544 (S.D. Cal. 1946).

43. See Strum, Mendez v. Westminster, 37.

44. CSO Tarango interview, 7; Arriola, "Knocking on the Schoolhouse Door," 185; Strum, Mendez v. Westminster, 37-39; Ruiz, "We Always Tell Our Children They Are American," 25. The court testimony of Gonzalo Mendez indicates that he was working alongside the LAVL by August 1944. Mendez's testimony also refers to a group of parents in Westminster referred to as the "Father's Association," which was formed between 1943 and 1944 with the purpose of challenging segregation in Orange County's schools. It is unclear whether the Father's Association and the LAVL were the same group, but it appears that the groups had overlapping memberships. See Mendez et al. v. Westminster School District of Orange County et al., 64 F.Supp. (S.D. Cal.1946).

45. Westminster Elementary School Board of Trustees, minutes, September 19, 1944; Mendez et al. v. Westminster School District of Orange County et al., 64 F.Supp. (S.D. Cal.1946).

46. Petition to Westminster Unified School District, September 8, 1944, Mendez et al. v. Westminster et al. Archive, Frank Mt. Pleasant Library of Special Collections and Archives, Chapman University, Orange, California, Box 3, Folder 1.

47. Westminster Elementary School Board of Trustees, minutes, September 19, 1944.

48. Mendez et al. v. Westminster School District of Orange County et al., 64 F.Supp. (S.D.

Cal.1946); Strum, Mendez v. Westminster, 48.

49. Ibid., 129-31; Santa Ana Board of Education, minutes, October 25, 1943.

50. Santa Ana Board of Education, minutes, October 23, 1944; Strum, Mendez v. Westminster, 129-31; Arriola, "Knocking on the Schoolhouse Door," 183.

51. CSO Tarango interview, 7; Gonzalez, interview with Hector Tarango, April 15, 1989; Arriola, "Knocking on the Schoolhouse Door," 182-85; Bernstein, Bridges of Reform, 188-92; 


\section{Placing the et al. Back in Mendez v. Westminster 51}

Strum, Mendez v. Westminster, 35-53, 129-31. For more on Marcus's central role in litigating civil rights victories on behalf of Mexican American communities in southern California, see Genevieve Carpio, "Unexpected Allies: David C. Marcus and His Impact on the Advancement of Civil Rights in the Mexican-American Legal Landscape of Southern California," in Beyond Alliances: The Jewish Role in Reshaping the Racial Landscape of Southern California, ed. George Sánchez (West Lafayette, IN: Purdue University Press, 2012), 1-32.

52. Westminster School Board of Trustees, minutes, January 10, 1945.

53. Ibid. Interestingly, in the very same meeting, the Westminster board approved the admission of "children of Japanese descent" at Westminster Main despite the fact that, at the time, California law allowed for their segregation.

54. Westminster School Board of Trustees, minutes, January 16, 1945; Mendez et al. v. Westminster School District of Orange County et al., 64 F.Supp. (S.D. Cal.1946).

55. Westminster School Board of Trustees, minutes, January 16, 1945.

56. Westminster School Board of Trustees, minutes, March 12, 1945; Santa Ana Board of Education, minutes, March 12, 1945.

57. Carey McWilliams, "Is Your Name Gonzales?," The Nation, April 8, 1947; Foley, Quest for Equality, 108-10; Alvarez, "The Lemon Grove Incident." Cal.1946)

58. Mendez et al. v. Westminster School District of Orange County et al., 64 F.Supp. (S.D.

59. Ibid., 123-27.

60. Ibid., 128-29.

61. The term "commercial-civic-citrus-elite" is borrowed from Gabriele Gonder Carey, "From Hinterlands to Metropolis: The Origins of Land Use Planning in Orange County, California, 1925-1950" (PhD diss., University of California, Riverside, 1997).

62. Westminster School Board of Trustees, minutes, March 29, 1946; Joel Ogle, letter to Richard Harris, District Superintendent of Westminster Schools, April 23, 1946, Westminster Unified School District; Strum, Mendez v. Westminster, 121-31.

63. McWilliams, "Is Your Name Gonzales?";"School Bias Draws Blast from Justices," Pittsburgh Courier, April 26, 1947. See also "Ruling Gives Mexican Children Equal Rights," Los Angeles Times, February 19, 1946.

64. Frederick P. Aguirre, "Mendez v. Westminster School District: How It Affected Brown v. Board of Education," Journal of Hispanic Higher Education 4, no. 4 (October 2005): 326. See also Bernstein, Bridges of Reform, 189-90; Strum, Mendez v. Westminster, 133-40; and Foley, Quest for Equality, 102-8.

65. CSO Tarango interview, 4-6; Santa Ana LULAC Council \#147, minutes, May 8, 1946, CSO History Project, Stanford, California; Celeste Navejas, "LULAC Honors Orange County Chapter Founders," Orange County Register, May 20, 2006; Mendez et al. v. Westminster et al. Archive, Frank Mt. Pleasant Library of Special Collections and Archives, Chapman University, Orange, California, Box 2, Folder 16; Strum, Mendez v. Westminster, 131. 79-88.

66. Bernstein, Bridges of Reform, 185-92; Brilliant, The Color of American Has Changed,

67. For more on Ross, see Gabriel Thompson, America's Social Arsonist: Fred Ross and Grassroots Organizing in the Twentieth Century (Berkeley: University of California Press, 2016).

68. CSO Tarango interview, 4-5; Fred Ross, letter to Hector Tarango, October 20, 1946, CSO History Project, Stanford, California; Ross, unpublished autobiography, 39-40; Bernstein, Bridges of Reform, 189-90; Garcia, A World of Its Own, 234-36; Strum, Mendez v. Westminster, 129-32.

69. CSO Tarango interview, 7; Ross, unpublished autobiography, 7.

70. Ross, unpublished autobiography, 9-14.

71. CSO Tarango interview, 7; Ross, unpublished autobiography, 32.

72. Ross, unpublished autobiography, 12-16, 20, 25-29; Hector Tarango, "Vote Yes on Proposition No. 11 and Smash Discrimination," letter to Mexican American Voters in Orange County, Circa October 1946, CSO History project, Stanford, California; Daniel HoSang, Racial Proposition: Ballot Initiatives and the Making of Postwar California (Berkeley: University of California Press, 2010), 24-52.

73. Strum, Mendez v. Westminster, 128.

74. Ross, unpublished autobiography, 29.

75. Santa Ana Board of Education, minutes, September 12, 1946.

76. Gonzalez, Chicano Education in the Era of Segregation, 137-39.

77. Santa Ana Board of Education, minutes, September 14, 1946.

78. Ross, unpublished autobiography, 29; Strum, Mendez v. Westminster, 129.

79. Ross, unpublished autobiography, 29-40.

80. Ross, unpublished autobiography, 40-42; El Modena Elementary School District, minutes, October 9, 1946, Mendez v. Westminster Archive, Chapman University, Orange, California, Box 3, Folder 1.

81. Ross, unpublished autobiography, 49; Strum, Mendez v. Westminster, 143. 


\section{David-James Gonzales}

82. Strum, Mendez v. Westminster, 148; Arriola, "Knocking on the Schoolhouse Door," 200.

83. Aguirre, Mendez v. Westminster School District, 327.

84. Robert L. Carter, interview with Sandra Robbie, 2003. See Mendez v. Westminster: For All The Children/Para Todos Los Ninos, DVD, dir. Sandra Robbie (Los Angeles: KOCE-TV Foundation, 2003).

85. For a discussion of the nuances between the legal strategy and argumentation employed in Mendez and Brown, see Brilliant, The Color of America Has Changed, 58-88, and Foley, Quest for Equality, 94-139.

86. Community Service Organization, History Project records, M1669, Department of Special Collections and University Archives, Stanford University Archives, Stanford California. 